\title{
Learners' Willingness to Communicate in a Foreign Language: The Role of Informal Digital Learning of English
}

\author{
Arif Nugroho \\ Universitas Islam Negeri Raden Mas Said Surakarta \\ arif.nugroho@iain-surakarta.ac.id
}

Article History

Received: 04 November 2021

Reviewed: 14 November 2021

Accepted: 09 December 2021

Published: 20 December 2021

Keywords: informal learning, informal digital learning of English, willingness to communicate in English, Indonesian EFL learners

\begin{abstract}
The trend of online teaching and learning in the age of the COVID-19 pandemic has driven contemporary students to learn English in an informal context outside the classroom. Drawing on this issue, the present study is at the cutting edge of examining the role of Informal Digital Learning of English (IDLE) in affecting students' willingness to communicate in a foreign language. A total of 156 (male=63; female=93) Indonesian EFL students participated in survey research upon invitation. The data are obtained by means of an online questionnaire consisting of three parts: (1) willingness to communicate, (2) IDLE, and (3) demographic data. The hierarchical regression analysis results reveal that Frequency of IDLE, Receptive IDLE activity, and Productive IDLE activity are the positive predictors of EFL learners' willingness to communicate in English as a foreign language. The results indicate that the Indonesian EFL learners are motivated to communicate in English when engaging in a range of IDLE activities. In other words, it is implied that IDLE activities (both productive and receptive) potentially build the communication behavior of Indonesian EFL learners, who learn English as a foreign language and possess a culturally homogeneous society.
\end{abstract}

\section{INTRODUCTION}

The shifting of learning mode from face-to-face classroom interaction to informal online activities resulted by COVID-19 pandemic has made changes on the way of English as a Foreign language (EFL) learners' learning style. Informal learning outside the classroom becomes an alternative to enhance language skills (Lai et al., 2016; Lai \& Zheng, 2018). In this learning environment, learners are encouraged to perform and develop autonomous learning outside a formal classroom with or without supervision from instructors or teachers (Naghdipour, 2017; Triana \& Nugroho, 2021). Self-directed learning outside the formal classroom using digital technology is referred to as Informal digital learning of English (Lee, 
2019). In this context, the issue of Informal digital learning of English (IDLE) is now becoming an interesting attribute to explore in the English language teaching (ELT) practice.

Studies related to IDLE have been conducted in recent years. Lee (2019) examines the contribution of IDLE in improving learners' second language vocabulary outcomes. The result shows that the quality of IDLE activities was significantly, positively associated with vocabulary performances. It implies that learners' engagement in a range of IDLE activities such as watching English videos online, reading news online, and posting English contents is crucial for acquiring second language vocabulary. Moreover, Lee (2020) explores the potential connection between IDLE activity and cross-cultural communicative competence. The result reveals that learners' perception of English varieties successfully moderated the connection between IDLE activities and strategic competence for cross-cultural communication. This result encourages ELT teachers and instructors to prepare English learners to develop cross-cultural interactions through face-to-face and digital milieus.

More recently, Nugroho and Atmojo (2020) scrutinize EFL learners' perception and teaching activities of digital learning of English beyond the classroom. Drawing on a webbased survey and semi-structured interview, the result depicts that the students have positive perception toward the use of digital technology to learn English outside the classroom. The use of social media such as Facebook, Instagram, and Youtube can facilitate the practice of EFL learners' language development. Furthermore, Lee and Lee (2021) research how IDLE and learners' motivational self-system correlate to foreign language enjoyment (FLE). The result of regression analysis shows that IDLE and motivational self-esteem are significantly predictive of all groups' FLE. The result indicates that learners' engagement in extramural digital activities beyond the classroom and their motivational mindset potentially impacts their emotion and enjoyment in learning the target language.

Previous studies have demonstrated the positive relationship between IDLE activities and some areas of English language development. The relationship between IDLE activities and other aspects of language development is worthy of exploring. From the review of the previous studies, a research gap is observable. To the best of the author's knowledge, the potential connection between IDLE activities and the learners' willingness to communicate in a foreign language remains unexplored, particularly in the Indonesian ELT context. Hence, the present study aims to shed some light on the role of IDLE activities (both productive and receptive) in developing Indonesian EFL learners' willingness to communicate. The results of this study offer valuable insights for ELT practitioners (teachers and instructors) to design an 
integrated learning mode (both formal and informal) by using digital technology that the students often engage with.

\section{LITERATURE REVIEW}

\section{Informal Digital Learning of English}

With the increasing trend of learning a foreign language using digital technology, language learning and teaching beyond the classroom (LBC) has gained much attention from ELT practitioners (Reinders \& Benson, 2017). In recent years, the change of learning mode from face-to-face to online learning outside the classroom provides ample opportunity for English learners to perform outside the classroom in an informal context. Lee (2019) refers to this learning mode as Informal digital learning of English (IDLE), which is further elucidated as English learning practices performed by learners in an informal context with the assistance of digital devices such as mobile phones, computers, and tablets. Lee (2019) has also emphasized that language learners commonly carry out both receptive IDLE activity and productive IDLE activity. The former indicates English learning activities where learners obtain knowledge and information as passive consumers (e.g., reading news, listening to English content, and watching English videos). On the other hand, the latter refers to English learning activities in which learners generate knowledge and information as active producers (e.g., chatting in English, writing comments in English, or sending emails to others in English).

\section{Willingness to Communicate in the Target Language}

In learning a second or foreign language, some students become willing to communicate with others in the target language, whereas others do not (Ghonsooly et al., 2012; Peng \& Woodrow, 2010). Since the establishment of the theory, scholars have begun investigating how willingness to communicate can be directly or indirectly affected by individual factors such as gender, age, anxiety, motivation, and social background (Şener, 2014). Concurrently, researchers have begun to realize that willingness to communicate can be focused on state-like variables such as social support, students' and teachers' use of foreign language, and e-resources. Therefore, it is in line with the aim of this research that is to examine a group of EFL learners' willingness to communicate. 


\section{METHODOLOGY}

\section{Research Design and Context}

This study portrays the potential relationship between informal digital learning of English (both receptive and productive) and EFL learners' willingness to communicate in a foreign language (English). To achieve the objective, a quantitative approach using regression analysis was employed. This study was based in the Indonesian context which English is taught as a foreign language. The most potential environment where learners are exposed to the foreign language is a formal classroom (Nugroho \& Rahmawati, 2020). However, the recent two years have witnessed the global pandemic of COVID-19. There is a shift from face-to-face classroom interaction to an online classroom environment using digital technology. Therefore, the idea of examining the role of informal digital learning of English (as a foreign language in Indonesia) comes up as an effort to facilitate self-directed language learning outside the classroom.

\section{Participants}

A total of 156 EFL learners (male $=63$; female $=93$ ) participated in this study upon invitation. They are native speakers of Indonesia and learning English as a foreign language. They enrolled in English language teaching and linguistic studies at a public university in Surakarta, Central Java, Indonesia. They are between 17-20 years old, and their average age is 18 .

\section{Instruments and Data Collection}

Considering the accessibility, the data in this study were obtained using an online questionnaire. The questionnaire was adapted from Lee and Sylvén (2021) and Lee and Drajati (2019), consisting of three parts: (1) Willingness to Communicate (WTC), (2) Informal digital learning of English (IDLE), and (3) demographic data. It was adapted to the current situation, culture, and environment of the Indonesian ELT context. To examine the learners' willingness to communicate, first, a five-item questionnaire was utilized (i.e. 'when you are given a chance to talk freely in an English class'; and other five items). All items were measured using 5 -point Likert scale ( 1 = definitely not willing; $5=$ definitely willing). Second, 10 questionnaire items of IDLE activities both receptive and productive (i.e. 'I read English news online', 'I watch English videos in Youtube', and other eight items) were utilized. The items were examined using a 5-point Likert scale ranging from $1=$ never to $5=$ 
very often (many times per day). The participants were also required to answer one item about the frequency of IDLE activities, i.e. 'how many hours did you spend daily on IDLE activities in the past three months?'. They were asked to respond in a range of frequency, from 'none' (coded 1), 'less than 1 hour' (coded 2), '1-2 hours' (coded 3), '2-3 hours' (coded 4), and 'more than 3 hours' (coded 5). Lastly, the participants were to fill out demographic information such as age, gender, length of learning English, and participating experience in English-speaking activities.

\section{Data analysis}

First, descriptive statistics such as mean (M) and standard deviation (SD) were administered to portray the characteristics of the data using the IBM SPSS Statistics 24 version. Second, the validity and reliability of the questionnaire were checked and considered valid since all items' scores did not exceed 0.05, and the Pearson correlation value was positive. The reliability was examined using Cronbach's alpha $(\alpha)$, and it turned out that the value for all items exceeded the minimum threshold of 0.6 (reliable). Third, a hierarchical regression analysis was employed to predict the potential relation between Frequency of IDLE, Receptive IDLE activity, Productive IDLE activity, and the learners' willingness to communicate (WTC).

\section{FINDINGS}

The Connection between Frequency of IDLE, Receptive IDLE, Productive IDLE Activity, and Willingness to Communicate

The main question of this study is whether Informal digital learning of English (IDLE) activities have an influence on the EFL learners' willingness to communicate. To this end, a hierarchical regression analysis was conducted by using the 156 participants' responses. Table 1 presents the results of data analysis about the connection between frequency of IDLE, receptive IDLE, and productive IDLE activities and EFL learners' willingness to communicate in English. Table 1 demonstrates that the three dimensions of Informal digital learning of English are the positive predictors for learners' willingness to communicate in a foreign language (all $\mathrm{p}$ values are lower than 0.05). 
Table 1. The connection among the variables

\begin{tabular}{llcccc}
\hline \multirow{2}{*}{ No. } & & \multicolumn{4}{c}{ Participants (n=156) } \\
\cline { 3 - 6 } & & $\mathbf{1}$ & $\mathbf{2}$ & $\mathbf{3}$ & $\mathbf{4}$ \\
\hline 1 & IDLE frequency & - & & & \\
2 & IDLE receptive & $0.012^{*}$ & - & & \\
3 & IDLE productive & $0.041^{*}$ & $0.047^{*}$ & - & \\
4 & Willingness to communicate & $0.026^{*}$ & $0.034^{*}$ & $0.012^{*}$ & - \\
\hline$* \mathrm{p}$ & $<0.05$ & & &
\end{tabular}

Furthermore, table demonstrates that receptive IDLE $(\beta=0.025, \mathrm{p}<0.05)$, productive $\operatorname{IDLE}(\beta=0.014, \mathrm{p}<0.05)$, and frequency of IDLE $(\beta=0.014, \mathrm{p}<0.05)$ are statistically significant predictors of EFL learners' willingness to communicate. It also indicates that these variables explain $29 \%$ of the total variance in the learners' willingness to communicate.

Table 2. Hierarchical regression analysis predicting the learners' willingness to communicate

\begin{tabular}{|c|c|c|}
\hline \multirow{2}{*}{ Predictor } & \multicolumn{2}{|c|}{ Participants (n=156) } \\
\hline & Model $1 \beta$ & Model $2 \beta$ \\
\hline Frequency of IDLE & & $0.014 *$ \\
\hline Receptive IDLE & & $0.025^{*}$ \\
\hline Productive IDLE & & $0.014 *$ \\
\hline $\mathrm{R}^{2}$ & 0.05 & 0.29 \\
\hline Change of $R^{2}$ & & 0.16 \\
\hline
\end{tabular}

$* \mathrm{p}<0.05$

\section{DISCUSSION}

The results of this study show that the frequency of IDLE, receptive IDLE activities and productive IDLE activities are the positive predictors of EFL learners' willingness to communicate. In general, the results depict that EFL learners who intensively engage in a range of Informal digital learning practices, both receptive and productive, are more willing to communicate in a foreign language. In other words, the more EFL learners engage in digital learning activities such as watching English videos, reading news online, and posting English content, the higher their motivation to communicate in a foreign language.

First, the frequency of IDLE is found to be a positive predictor of the learners' willingness to communicate in English. This result supports the finding of Lee (2019), revealing that the number of IDLE activities could enhance learners' second language vocabulary outcomes and therefore develop their communication skills. It implies that English learners who master a lot of vocabularies will be able to speak in the target 
language and enhance their communicative competence (Nugroho et al., 2021). This result encourages teachers and instructors to enhance the quantity of digital learning activities that integrate digital technology in an informal context, of course under a stable internet connection.

Second, receptive IDLE activities (e.g., reading online news in English, listening to English contents) are also the positive predictor of EFL learners' willingness to communicate in English. This result is consistent with the finding of Wijaya et al. (2021) and Lai and Zheng (2018), depicting that performing a range of self-directed receptive language learning could potentially develop learners' motivation to be engaged in the target language communication activities. This finding suggests that receptive IDLE activities are a promising learning practice to improve the EFL learners' speaking skill (Mutiaraningrum $\&$ Nugroho, 2020). Hence, it is highly suggested for teachers and instructors to integrate the receptive IDLE activities in their designed English classroom activities.

Third, productive IDLE activities (e.g., posting English content, chatting in English) effectively encourage EFL learners' willingness to communicate. This result is similar to the finding of Lee and Sylvén (2021) that informal digital learning of English (particularly productive IDLE) has a crucial role in developing EFL learners' communication behavior. It implies that productive IDLE activities could facilitate the target language communicative competence of EFL learners (Makruf et al., 2021; Wardani \& Suharto, 2021). Therefore, this study suggests ELT teachers develop a productive IDLE activity learning environment.

\section{CONCLUSION}

The present study aims at exploring the potential connections between Informal digital learning of English (IDLE) activities and Indonesian EFL learners' willingness to communicate. Drawing on a hierarchical regression analysis, the results reveal that frequency of IDLE, receptive IDLE, and productive IDLE activities are the positive predictors of Indonesian EFL learners' willingness to communicate. The results suggest that the more EFL learners engage in IDLE activities, the higher their motivation to be involved in the target language communication. The results contribute to English language teaching practices in terms of offering valuable insights and a clear description of the role of informal digital learning of English activities in enhancing EFL learners' communication behavior. Apart from these compelling results, this study is limited in terms of the portrayal of an in-depth 
understanding of the EFL learners' practices of IDLE activities (what digital tool they perform, what devices, and how they implement their learning). Therefore, future studies are encouraged to conduct an immense project to depict a more in-depth description of the practices and implementation of IDLE activities qualitatively.

\section{REFERENCES}

Ghonsooly, B., Khajavy, G. H., \& Asadpour, S. F. (2012). Willingness to communicate in English among Iranian non-English major university students. Journal of Language and Social Psychology, 31(2), 197-211.

Lai, C., Wang, Q., Li, X., \& Hu, X. (2016). The influence of individual espoused cultural values on self-directed use of technology for language learning beyond the classroom. Computers in Human Behavior, 62, 676-688. https://doi.org/10.1016/j.chb.2016.04.039

Lai, C., \& Zheng, D. (2018). Self-directed use of mobile devices for language learning beyond the classroom. ReCALL, 30(3), 299-318. https://doi.org/10.1017/S0958344017000258

Lee, J. S. (2019). Informal digital learning of English and second language vocabulary outcomes: can quantity conquer quality? British Journal of Educational Technology, 50(2), 767-778. https://doi.org/10.1111/bjet.12599

Lee, J. S. (2020). Informal digital learning of English and strategic competence for crosscultural communication: perception of varieties of English as a mediator. ReCALL, 32(1), 47-62. https://doi.org/10.1017/S0958344019000181

Lee, J. S., \& Drajati, N. A. (2019). English as an international language beyond the ELT classroom. ELT Journal, 73(4), 419-427. https://doi.org/10.1093/elt/ccz018

Lee, J. S., \& Lee, K. (2021). The role of informal digital learning of English and L2 motivational self system in foreign language enjoyment. British Journal of Educational Technology, 52(1), 358-373.

Lee, J. S., \& Sylvén, L. K. (2021). The role of informal digital learning of English in Korean and Swedish EFL learners' communication behaviour. British Journal of Educational Technology, 52(3), 1279-1296. https://doi.org/10.1111/bjet.13082

Makruf, I., Putra, H.R., Choiriyah, S., \& Nugroho, A. (2021). Flipped learning and communicative competence: an experimental study of English learners. International Journal of Education in Mathematics, Science and Technology, 9(4), 571-584.

Mutiaraningrum, I., \& Nugroho, A. (2020). Social construction of knowledge in synchronous text-based discussion during English language learning. Journal on English as a Foreign Language, 10(2), 315-336. https://doi.org/10.23971/jefl.v10i2.1934 
Naghdipour, B. (2017). 'Close your book and open your facebook': a case for extending classroom collaborative activities online. Journal of Asia TEFL, 14(1), 130-143. https://doi.org/10.18823/asiatefl.2017.14.1.9.130

Nugroho, A., \& Atmojo, A. E. P. (2020). Digital learning of English beyond classroom: EFL learners'perception and teaching activities. JEELS (Journal of English Education and Linguistics Studies), 7(2), 219-243.

Nugroho, A., Haghegh, M., \& Triana, Y. (2021). Emergency remote teaching amidst global pandemic: voices of Indonesian EFL teachers. VELES Voices of English Language Education Society, 5(1), 66-80.

Nugroho, A., \& Rahmawati, A. (2020). "Let's write a caption!": utilizing instagram to enhance ESP students' writing skills. JURNAL BASIS, 7(1), 1-12.

Peng, J., \& Woodrow, L. (2010). Willingness to communicate in English: a model in the Chinese EFL classroom context. Language Learning, 60(4), 834-876.

Reinders, H., \& Benson, P. (2017). Language learning beyond the classroom: a research agenda. Language Teaching, 50(4), 561-578.

Şener, S. (2014). Turkish ELT students' willingness to communicate in English. ELT Research Journal, 3(2), 91-109.

Triana, Y., \& Nugroho, A. (2021). Brief ELT in digital classroom for lazy creative lecturers (option after post pandemic recovery): lecturers' perspectives. Indonesian Journal of EFL and Linguistics, 6(1), 79-99.

Wardani, A., \& Suharto, T. (2021). Optimizing the role of informal learning in the perspective of Islamic education during the Covid-19 pandemic. Journal of Educational Management and Instruction (JEMIN), 1(1), 28-39. doi:https://doi.org/10.22515/jemin.v1i1.3456

Wijaya, S. A., Asib, A., \& Suparno, S. (2021). Portraying informal digital learning of English from management, beliefs, and practices. Register Journal, 14(2). https://doi.org/10.18326/rgt.v14i2.\%25p 